\title{
The Profile of Anti-inflammatory Activity of Syzigium Aromaticum Volatile Oil in Lotion with Variation Composition of Oleic Acid and Propylene Glycol as Enhancer
}

\section{Profil Daya Anti-inflamasi Minyak Atsiri Bunga Cengkeh (Syzigium Aromaticum) dalam Sediaan Lotion dengan Variasi Komposisi Asam Oleat dan Propilen Glikol sebagai Enhancer}

\author{
Fitriah Ardiawijianti Iriani, Nining Sugihartini*, Tedjo Yuwono \\ Fakultas Farmasi Universitas Ahmad Dahlan, Jl. Prof. Dr. Soepomo, S.H. Janturan, Yogyakarta 55164
}

\begin{abstract}
Essential oil of clove (Syzygium aromaticum) containing eugenol has an anti-inflammatory activity. The study was aimed to develop the formulation of lotion by adding of oleic acid and propylene glycol as penetration enhancer. The effect of enhancer composition was also studied. Lotion was prepared with the composition of oleic acid (AO) and propylene glycol (PG) as follow: 1:0 (FI), 0,5:0,5 (FII), 0:1 (FIII). Capacity an anti-inflammatory of formulation based on parameters of the amount of cells with COX-2 expression, the number of inflammatory cells and the epidermis thickness was evaluated using male mouse strain BALb/C induced by crotton oil as inflammatory agents. The results showed that the increasing composition propylene glycol caused the decreasing of the amount of cells with COX-2 expression $(p<0.05)$, the inflammatory cells $(P$ $<0.05)$ and the epidermis thickness ( $p<0.05)$.
\end{abstract}

Key words: essential oil of clove, lotion, oleic acid, propylene glycol, anti-inflammatory

\begin{abstract}
ABSTRAK
Minyak atsiri bunga cengkeh (Syzygium aromaticum) dengan bahan aktif eugenol telah terbukti berkhasiat sebagai antiinflamasi dalam bentuk sediaan lotion. Tujuan dari penelitian ini adalah mengembangkan formulasi lotion dengan penambahan asam oleat dan propilen glikol sebagai enhancer. Selain itu juga dipelajari komposisi dari enhancer tersebut. Lotion dibuat dengan komposisi asam oleat (AO) dan propilen glikol (PG) sebagai berikut: 1:0 (FI); 0,5:0,5 (FII); 0:1 (FIII). Kapasitas sediaan sebagai antiinflamasi dengan parameter jumlah sel dengan ekspresi COX-2, jumlah sel radang dan tebal epidermis dievaluasi menggunakan hewan uji mencit jantan galur BALb/C yang diinduksi dengan crotton oil sebagai agen inflamasi. Hasil penelitian menunjukkan bahwa peningkatan komposisi propilen glikol menyebabkan penurunan jumlah sel dengan ekspresi COX-2 $(p<0,05)$, jumlah sel radang $(p<0.05)$ dan tebal epidermis $(p<0.05)$.
\end{abstract}

Kata kunci: minyak atsiri bunga cengkeh, lotion, asam oleat, propilen glikol, antiinflamasi

\section{PENDAHULUAN}

Inflamasi merupakan respon protektif setempat yang disebabkan oleh cedera atau kerusakan pada jaringan yang berfungsi untuk menghancurkan, mengurangi, atau melokalisasi baik agen pencedera maupun jaringan yang cedera itu (Erlina dkk., 2007). Pada beberapa tahun terakhir ini banyak metabolit sekunder tanaman menunjukan aktivitas sebagai penghambat cyclooxigenase. Golongan utama yang merupakan senyawa penghambat cyclooxigenase

Correspondence author: Nining Sugihartini

Email : nining.sugihartini@pharm.uad.ac.id adalah flavonoid, fenolik dan beberapa stilbenoid. Senyawa fenolik seperti gingerol, eugenol dan curcuminoid menunjukan penghambatan terhadap aktivitas cyclooxigenase secara signifikan (Jachak, 2006).

Minyak cengkeh merupakan minyak atsiri yang berasal dari tanaman cengkeh (Syzygium aromaticum) yang memiliki aktivitas biologis karena mengandung senyawa eugenol dan diketahui berkhasiat sebagai antiinflamasi dengan mekanisme menghambat sintesis prostaglandin dan neutrofil chemotaxis (Murakami dkk., 2003). Berdasarkan penelitian Sugihartini dkk. (2015) diketahui bahwa dosis optimum minyak atsiri 
bunga cengkeh untuk sediaan lotion sebagai antiinflamasi adalah 10\%. Kemampuan lotion minyak atisiri bunga cengkeh sebagai antiinflamasi diharapkan dapat meningkat dengan cara penambahan enhancer. Enhancer merupakan zat tambahan yang dimaksudkan untuk meningkatkan jumlah zat yang terpenetrasi agar dapat digunakan untuk tujuan pengobatan sistemik melalui kulit (Songkro, 2009). Jenis enhancer yang digunakan dalam penelitian ini adalah asam oleat dan propilen glikol. Hendriati dkk. (2012) menunjukkan bahwa penggunaan asam oleat dan propilen glikol meningkatkan harga available dose propranolol $\mathrm{HCl}$. Hal ini diduga terjadi karena efek sinergisme kombinasi antara asam oleat dengan kosolven propilen glikol, sehingga efek asam oleat menjadi lebih besar.

\section{METODE}

\section{Alat dan Bahan}

Bahan-bahan yang digunakan dalam penelitian ini meliputi minyak atsiri bunga cengkeh terstandar kadar eugenol sebesar 88,92\% (Sugihartini dkk., 2015) yang diperoleh dari Pusat Studi Minyak Atsiri / Center of Essential Oils Studies (CEOS) Universitas Islam Indonesia, bahan-bahan pembuat lotion dan enhancer dengan kualitas farmasetis yang diperoleh dari Brataco Chem (setil alkohol, asam stearat, trietanolamin, gliserin, metil paraben, propil paraben, asam oleat, propilen glikol, aquadest), croton oil (Sigma) dan veed. Selain itu digunakan peralatan mikroskop (Olympus).

\section{Hewan Uji}

Pada penelitian ini digunakan hewan uji berupa mencit jantan galur BALB/C dengan berat 25-30 g yang diperoleh dari Laboratorium Penelitian dan Pengujian Terpadu (LPPT), UGM. Sebelum perlakuan maka mencit diadaptasikan selama 6 hari. Selama penelitian maka mencit ditempatkan dalam kandang plastik berukuran 30x40 cm (satu kandang untuk 6 ekor). Selain itu kandang dikondisikan dalam suhu kamar serta adanya siklus cahaya terang gelap setiap 12 jam. Selain itu juga disediakan pakan dan minum secara ad libitum. Penelitian ini telah mendapatkan persetujuan etik dari Komite Etik Universitas Ahmad Dahlan dengan No.011508062.

\section{Cara Kerja \\ Pembuatan lotion minyak atsiri bunga cengkeh}

Formula lotion minyak atsiri bunga cengkeh yang digunakan mengacu pada penelitian Sugihartini dkk. (2015) yang menunjukkan bahwa konsentrasi yang optimal adalah 10\%. Selanjutnya dalam formula tersebut ditambahkan enhancer asam oleat dan propilen glikol yang komposisinya ditentukan berdasarkan metode Simplex Lattice Design seperti disajikan pada tabel I.

Lotion dibuat dengan metode peleburan di mana bahan-bahan dibagi menjadi dua bagian yaitu bahan yang larut minyak (fase minyak) dan bahan yang larut air (fase air). Bahan-bahan yang termasuk fase minyak antara lain setil alkohol, asam stearate, asam oleat dimasukkan ke dalam cawan porselen dan dipanaskan pada suhu $60^{\circ} \mathrm{C}$. Di sisi lain bahan-bahan yang termasuk fase air seperti trietanolamin, propil paraben, metil paraben dan propilen glikol juga dilarutkan dalam aquades dan dipanaskan pada suhu yang sama. Setelah itu fase minyak dan fase air dicampur dan diaduk hingga homogen. Setelah lotion dingin dimasukkan minyak atsiri bunga cengkeh dan diaduk hingga campuran tersebut homogen (Anita, 2008).

\section{Uji daya antiinflamasi}

Pada penelitian ini digunakan 6 kelompok perlakuan yang masing-masing terdiri dari 6 ekor mencit. Kelompok pertama adalah kelompok kontrol sehat yaitu kelompok yang tidak mendapatkan perlakuan dan kelompok berikutnya adalah 5 kelompok yang diberi induksi inflamasi dilanjutkan perlakuan sesuai nama kelompoknya. Prosedur induksi inflamasi diawali pencukuran pada bagian punggung kemudian pengolesan perontok rambut. Setelah 24 jam punggung mencit tersebut ditetesi dengan $0,1 \mathrm{ml}$ croton oil konsentrasi 4\%. Setelah 30 menit dari penetesan croton oil, maka mencit diberi perlakuan sesuai jenis kelompoknya. Perlakuan tersebut berupa pengolesan sediaan seberat 100 mg. Sediaan yang diuji adalah sediaan yang ada di pasaran untuk kelompok kontrol positif, tidak diberi sediaan untuk kelompok kontrol negatif, lotion dengan penambahan enhancer asam oleat $100 \%$ untuk kelompok FI, lotion dengan penambahan enhancer asam oleat $50 \%$ dan propilen glikol 50\% untuk kelompok FII dan lotion dengan penambahan enhancer propilen glikol $100 \%$ untuk kelompok FIII.

Hari berikutnya juga diberi perlakuan penetesan croton oil dan pengolesan sediaan sesuai nama kelompoknya. Perlakuan tersebut diberikan selama 3 hari. Setelah itu mencit dikorbankan dan diambil jaringan bagian punggungnya untuk dibuat preparat pengecatan Hematoxylin, Eosin (HE) di Laboratorium Patologi Anatomi Fakultas Kedokteran Universitas Gadjah Mada sedangkan imunohistokimia dengan antibody anti-COX-2 dilakukan di Laboratorium Patologi Anatomi RS Dr. Sardjito Yogyakarta. 
Tabel I. Formula Sediaan Lotion minyak atsiri bunga cengkeh dengan penambahan Enhancer Asam Oleat dan Propilen Glikol

\begin{tabular}{lccc}
\hline Bahan & Formula I & Formula II & Formula III \\
\hline Minyak atsiri bunga cengkeh & 10 & 10 & 10 \\
Setil alcohol & 4 & 4 & 4 \\
Asam stearate & 4 & 4 & 4 \\
Trietanolamin & 2 & 2 & 2 \\
Gliserin & 2 & 2 & 2 \\
Metil paraben & 0,2 & 0,2 & 0,2 \\
Propil paraben & 0,03 & 0,03 & 0,03 \\
Aquadest & 67,77 & 67,77 & 67,77 \\
Enhancer asam oleat & 10 & 5 & 0 \\
Enhancer propilen glikol & 0 & 5 & 10 \\
Total & 100 & 100 & 100 \\
\hline
\end{tabular}

Keterangan :

Formula I : Formula Lotion dengan perbandingan AO 100\% : PG 0\%; Formula II : Formula Lotion dengan perbandingan AO 50\% : PG 50\%; Formula III : Formula Lotion dengan perbandingan AO 0\% : PG 100\%

Tabel III. Jumlah sel dengan ekspresi COX-2 pada kelompok perlakuan kontrol sehat, kontrol positif, kontrol negatif, lotion tanpa enhancer dan lotion dengan penambahan enhancer asam oleat $100 \%$ (FI), asam oleat 50\%:propilen glikol 50\% (FII) dan propilen glikol 100\% (FIII) (N=6)

\begin{tabular}{lccc}
\hline \multicolumn{1}{c}{ Perlakuan } & $\begin{array}{c}\text { Jumlah ekspresi } \\
\text { COX-2 (\%) }\end{array}$ & $\begin{array}{c}\text { Jumlah sel } \\
\text { radang }\end{array}$ & $\begin{array}{c}\text { Tebal epidermis } \\
(\boldsymbol{\mu m})\end{array}$ \\
\hline Kontrol sehat & $18,16 \pm 4,95$ & $13,17 \pm 2,32$ & $81,9 \pm 26,88$ \\
Kontrol positif & $31,23 \pm 2,41$ & $59,67 \pm 2,50$ & $107,2 \pm 8,42$ \\
Kontrol negatif & $43,63 \pm 3,57$ & $70,83 \pm 3,66$ & $228,0 \pm 12,95$ \\
Lotion tanpa enhancer & $31,25 \pm 1,91$ & $52,33 \pm 8,69$ & $167,3 \pm 16,44$ \\
Lotion FI & $30,47 \pm 0,86$ & $51,67 \pm 3,56$ & $163,8 \pm 6,87$ \\
Lotion FII & $29,12 \pm 1,28$ & $48,17 \pm 5,49$ & $162,4 \pm 4,81$ \\
Lotion FIII & $21,17 \pm 2,08$ & $45,00 \pm 1,79$ & $160,0 \pm 1,78$ \\
\hline
\end{tabular}

Berdasarkan hasil pengecatan diukur tebal epidermis, jumlah sel radang dan jumlah sel dengan ekspresi COX-2 menggunakan mikroskop cahaya (Olympus) di Laboratorium Kimia Organik Universitas Ahmad Dahlan Yogyakarta (Utami, 2016, Sugihartini, 2013). Tebal epidermis dalam satuan pixel dihitung pada bagian sel epidermis dengan menggunakan program (ToupView) yang dihubungkan dengan mikroskop cahaya (Olympus). Selanjutnya luas epidermis dikonversi dari satuan pixel menjadi mm kemudian diubah menjadi $\mu \mathrm{m}$ (Sari dan Yuliani, 2015). Jumlah sel radang dilakukan dengan menghitung jumlah sel neutrofil yang bermigrasi dan sel yang mengekspresikan COX-2 pada daerah subkutan jaringan kulit punggung mencit di bawah mikroskop cahaya (Olympus) dengan pembesaran 400x. Nilai persentase ekspresi COX-2 masing- masing perlakuan dihitung dengan persamaan (Utami, 2016) :

$\%$ ekspresi COX-2 $=\frac{\text { jumlah sel ekspresi COX }-2}{\text { total sel hitung }} \times 100 \%$

\section{HASIL DAN PEMBAHASAN}

Hasil uji daya antiinflamasi berdasarkan parameter tebal epidermis, jumlah sel radang dan jumlah sel dengan ekspresi COX-2 disajikan pada tabel II. Data tersebut kemudian dianalisis statistik dan diketahui adanya perbedaan signifikan antara kontrol sehat dan kontrol negatif. Ini menunjukkan bahwa induksi dengan croton oil mampu menimbulkan adanya inflamasi sehingga dapat dipergunakan untuk mengevaluasi daya antiinflamasi lotion minyak atsiri bunga cengkeh. Croton oil merupakan lokal iritan dan promoter inflamasi karena mengandung phorbol esters dan 12-0-tetradecanoylphorbol-13-acetat yang dapat menginduksi inflamasi. Senyawa 
tersebut mampu meningkatkan NF- $\kappa$ B yang dapat menginduksi papiloma pada kulit tikus. Croton oil juga dilaporkan mampu menimbulkan bengkak pada kulit dan dapat menginduksi terjadinya hyperplasia dan infiltrasi dari leukosit (Subramanian dan Vellaichany, 2014; Boligou dkk., 2017).

Hasil uji statistik antara kelompok lotion dengan penambahan enhancer (FI, FII dan FIII) dan kelompok yang diberi perlakuan lotion tanpa enhancer ternyata terdapat perbedaan yang signifikan. Tebal epidermis, jumlah sel radang dan jumlah sel dengan ekspresi COX-2 pada FI, FII, FIII lebih kecil dibandingkan kelompok yang diberi perlakuan lotion tanpa enhancer. Hal ini menunjukkan bahwa campuran enhancer yang dipergunakan mampu meningkatkan penetrasi eugenol sebagai zat aktif dalam minyak atsiri temulawak menembus lapisan kulit. Dengan semakin meningkatnya eugenol yang mencapai daerah inflamasi di bawah lapisan kulit maka efektifitasnya juga semakin meningkat. Hal ini didukung oleh penurunan tebal epidermis, jumlah sel radang dan jumlah sel dengan ekspresi COX-2 yang signifikan antara kelompok kontrol negatif dengan FI, FII dan FIII.

Pada penelitian ini dipergunakan variasi komposisi campuran enhancer asam oleat dan propilen glikol yang ditambahkan pada sediaan lotion dengan mengacu pada konsep Simplex Lattice Design (100\% asam oleat (FI), 50\% asam oleat dan 50\% propilen glikol (FII) dan 100\% propilen glikol (FIII)). Data yang diperoleh pada masing-masing formula tersebut (tabel II) kemudian dibuat kurva dengan menggunakan persamaan berdasarkan konsep Simplex Lattice Design seperti yang disajikan pada gambar 1, 2 dan 3. Berdasarkan kurva tersebut dapat diprediksi daya antiinflamasi lotion minyak atsiri bunga cengkeh pada berbagai variasi komposisi propilen glikol dan asam oleat yang digunakan sebagai enhancer. Berdasarkan gambar tersebut diketahui bahwa dengan semakin meningkatnya komposisi propilen glikol maka efektivitas antiinflamasi meningkat yang ditandai dengan semakin kecilnya tebal epidermis, jumlah sel radang dan jumlah sel dengan ekspresi COX-2. Hal ini nampak jelas pada perbedaan yang signifikan antara FI dan FIII pada data tebal epidermis dan sel radang. Mekanisme propilen glikol sebagai enhancer adalah dengan melarutkan lapisan keratin stratum korneum, berinteraksi dan mengganggu susunan lipid intraseluler pada stratum korneum sehingga pertahanan kulit menurun. Selain itu propilen glikol dapat meningkatkan kelarutan obat dalam stratum kornenum sehingga jumlah obat yang melewati kulit dapat meningkat (Ginting, 2014; Mohammed dkk., 2014; Lane, 2013; Santos dkk., 2012; Remon, 2007; Duracher dkk., 2009).

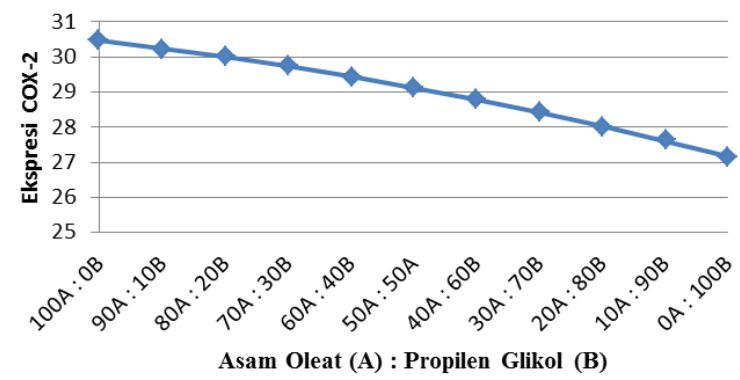

Gambar 1. Grafik hubungan jumlah ekspresi COX2 terhadap komposisi asam oleat dan propilen glikol

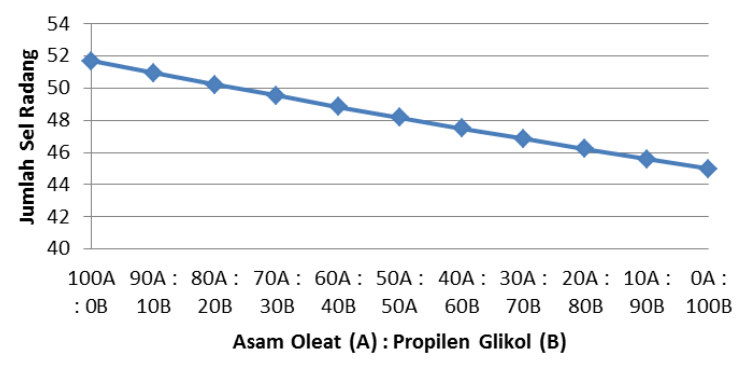

Gambar 2. Grafik Hubungan Jumlah Sel radang terhadap komposisi asam oleat dan propilen glikol

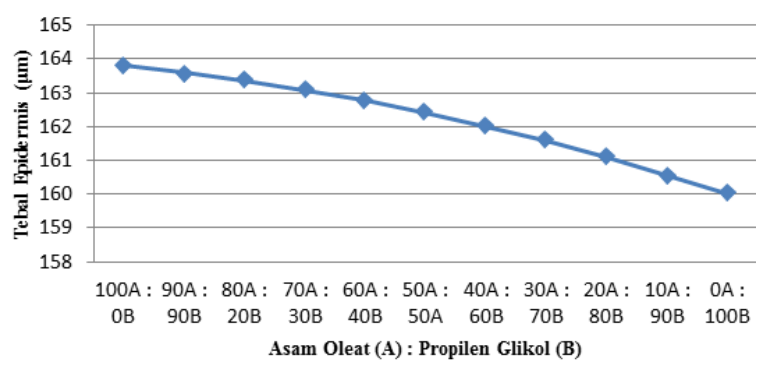

Gambar 3. Grafik hubungan tebal epidermis terhadap komposisi asam oleat dan propilen glikol

Peningkatan efektivitas lotion minyak atsiri bunga cengkeh dengan penambahan enhancer ternyata belum mampu mengembalikan kondisi kulit yang mengalami inflamasi ke kondisi sehat. Hal ini nampak karena masih ada perbedaan signifikan antara FI, FII dan FIII dengan kontrol sehat. Kemungkinan penyebabnya adalah singkatnya proses pengolesan sediaan lotion yaitu selama 3 hari sehingga belum cukup waktu untuk mengembalikan kondisi kulit ke keadaan sebelumnya. Apabila dibandingkan dengan kontrol positif maka jumlah sel radang dan jumlah sel dengan ekspresi COX-2 pada kelompok 
FI, FII dan FIII lebih kecil secara signifikan dibandingkan kontrol positif. Meskipun untuk tebal epidermis masih belum sama bahkan lebih tebal dibandingkan dengan kontrol positif. Dengan data tersebut dapat dinyatakan bahwa formula lotion dengan penambahan enhancer sudah memiliki aktivitas yang sama bahkan lebih baik dengan sediaan topikal antiinflamasi yang ada di pasaran khususnya pada parameter jumlah sel radang dan jumlah sel dengan ekspresi COX-2.

\section{KESIMPULAN}

Hasil uji menunjukkan bahwa komposisi enhancer asam oleat dan propilen glikol mempengaruhi daya antiinflamasi lotion minyak atsiri bunga cengkeh. Formula III dengan perbandingan AO 0\% : PG 100\% memiliki jumlah ekspresi COX-2, jumlah sel radang dan tebal epidermis yang paling kecil.

\section{UCAPAN TERIMAKASIH}

Penelitian ini terselenggara atas bantuan Hibah Penelitian Dikti melalui Skema Penelitian Hibah Tim Pascasarjana tahun 2016.

\section{DAFTAR PUSTAKA}

Anita, S.B., 2008, Aplikasi Karaginan dalam Pembuatan Skin Lotion. Skripsi. Institut Pertanian Bogor

Boligou, A.A., Moreira, L.R., Piana, M., Campos, M.M.A., Oleivera, S.M., 2017, Topical Anti Edematogenic and Anti-Inflammatory Effect of Scutia buxifolia Reissek Gel and Stability Study, J. Photochem. Photobiol., B, 167:29-35

Duracher, L., Blasco, L., Hubaud, J. C., Vian, L. dan Marti-Mestres, G., 2009, The Influence of alcohol, propylene glycol and 1,2pentanediol on the permeability of hydrophilic model drug through excised pig skin, Int. J Pharm., 374, 39-45

Erlina, R., A. Indah, dan Yanwirasti, 2007, Efek Antiinflamasi Ekstrak Etanol Kunyit (Curcuma domestica Val.) pada Tikus Putih Jantan Galur Wistar, Jurnal Sains dan TeknologiFarmasi, 12(2), 112-115.

Ginting, D., 2014, Formulasi Patch Natrium Diklofenak Berbasis Polimer HPMC dan NaCMC sebagai Antiinflamasi lokal pada penyakit periodontal. Skripsi, UIN Syarif Hidayatullah, Jakarta.

Hendriati, L., Nugroho, A.K., 2012, Optimasi Asam Oleat, Propilen Glikol dan Iontoforesis Terhadap Transpor Transdermal
Propranolol HCl. Jurnal Farmasi Indonesia, 6 (1) : 21-29

Jachak, S.M, 2006, Cyclooxygenase Inhibitory Natural Product: Current Status. Curr. Med. Chem., 13, 659-678.

Lane, M.E., 2013, Skin Penetration Enhancers, Int. J. Pharm., 447, 12-21

Mohammed, D., Hirata, K., Hadgraft, J., Lane, M., 2014, Influence of Skin Penetration Enhancers on Skin Barrier Function and Skin Protease Activity, Eur. J. Pharm. Sci., 51, 118-122

Murakami, Y., Shoji, M., Hanazawa, S., Tanaka, S., and Fujisawa, S., 2003. Preventive effect of bis-eugenol, a eugenol ortho dimer, on lipopolysaccharide-stimulated nuclear factor kappaB activation and inflammatory cytokine expression in macrophages, Biochem. Pharmacol., 66:1061-1066.

Remon ,J.P, 2007, Absorption Enhancers, in Encyclopedia of Pharmaceutical Technology, $3^{\text {rd }}$ edition, Swarbick. J (ed), Informa, New York

Santos, P., Watkonson, A.C., Hadgraft, J., Lane, M.E., 2012, Influence of Penetration Enhancer on Drug Permeation from Volatile Formulations, Int. J. Pharm., 260-268

Songkro S.2009. An overview of skin penetration enhancers:penetration enhancing activity, skin irritation potential and mechanism of action. Songklanakarin J. Sci. Technol. 31(3):299-321

Subramanian, V., Vellaichamy, E., 2014, Atrial Natriuretik Peptide (ANP) Inhibiting DMBA/Croton Oil Induced Skin Tumor Growth by Modulating NF- $\kappa \mathrm{B}$, MMPs and Infiltrating Mast Cells in Swis Albino Mice, Eur. J. Pharm., 740:388-397

Sugihartini, N., 2013, Optimasi Komposisi Enhancer dan Emulgator pada Formulasi Krim Fraksi Etil Asestat Ekstrak Teh Hijau (Camellia sinensis, L) sebagai Sediaan Topikal Anti Inflamasi, Disertasi, Program Pascasarjana UGM, Yogyakarta.

Sugihartini, N., Yuwono, T., Sofia, V., 2015, Optimasi Formulasi Minyak Atsiri Bunga Cengkeh (Syzygium aromaticum) Sebagai Sediaan Herbal Terstandar Antiinflamasi, Laporan Hibah Penelitian Tim Pascasarjana Universitas Ahmad Dahlan.

Utami, S. A., 2016, Uji Efek Antiinflamasi Topikal Ekstrak Milk Thistle ${ }^{\circledR}$ pada Jumlah Neutrofil dan Ekspresi COX-2 Mencit Betina Terinduksi Karagenin. Skripsi. Universitas Sanata Dharma, Yogyakarta 